\title{
Effect of Consortium of Endophytic Nitrogen Fixing Bacteria on Yield Observations of Seasonal (Suru) Sugarcane under Drip Irrigation
}

\author{
B. Rajkumar ${ }^{1 *}$, B.D. Bhakare ${ }^{1}$ and Jana Harish ${ }^{2}$ \\ ${ }^{1}$ Department of soil science and Agricultural Chemistry, ${ }^{2}$ Department of Irrigation and Water \\ Management, Post Graduate Institute, Rahuri (MPKV), Ahmednagar, Maharashtra-413722, India \\ *Corresponding author
}

\section{A B S T R A C T}

The present investigation entitled "Effect of consortium of endophytic nitrogen

Keywords

Nitrogen fixing bacteria, Yield and Observation.

Article Info

Accepted:

29 June 2017

Available Online:

10 July 2017 fixing bacteria on yield and quality of seasonal (Suru) sugarcane (Saccharum officinarum) under drip irrigation" was carried out at AICRP on Water Management, M.P.K.V., Rahuri during 2014-15. The experiment was laid out in Randomized Block Design with six treatments and four replications. There were four levels of nitrogen $(100 \%, 50 \%, 25 \%$ and $0 \%)$ with $\mathrm{P}_{2} \mathrm{O}_{5}, \mathrm{~K}_{2} \mathrm{O}$, PSB, FYM and foliar application of consortium of endophytic nitrogen fixing bacteria with and without combination and set treatment of Acetobacter diazotrophicus. The experiment conducted revealed that highest number of internodes, length of internodes, higher number of millable canes (9.17), top yield $\left(11.47 \mathrm{t}^{-\mathrm{ha}^{-1}}\right)$, cane yield $\left(284 \mathrm{t} . h a^{-1}\right)$ and cane dry matter weight $\left(79.63 \mathrm{t}^{-h^{-1}}\right)$ was recorded in the treatment $25 \% \mathrm{~N}+$ Consortium of Endophytic Bacteria foliar spray.

\section{Introduction}

Sugarcane (Saccharum spp. hybrid) is a tall, perennial grass (family Poaceae, subfamily Panicoide), and is cultivated in tropical and warm-temperate regions between $35^{\circ} \mathrm{N}$ and $35^{\circ} \mathrm{S}$ and from sea level to altitudes of 1,000 $\mathrm{m}$ in a wide variety of soil types (Reis et al 2007). Most of the commercial sugarcane varieties are hybrids with Saccharum officinarum. The optimal temperature for sugarcane cultivation is between 20 and $35^{\circ} \mathrm{C}$ and the minimum rainfall requirement is 1,200mm per year (Ando. 2010). The stalks (stems) of sugarcane are harvested at 9 to 18 months after planting the mother stem cutting (setts).
Once planted, sugarcane can be harvested several times, because new stalks, called ratoons, repeatedly grow from the stubble. For many years, sugarcane has been used for sugar and an alcoholic drink production. Sugarcane being a long duration crop produces huge amount of biomass, and requires large quantity of water (1100-2200 $\mathrm{mm}$ ) and is mostly grown as an irrigated crop using surface irrigation. The drip irrigation adoption in sugarcane increases water use efficiency (60-200\%), saves water (20-60\%), reduces fertilization requirement (20-33\%) through fertigation, produces better quality crop and increases yield (7-25\%) as compared with conventional irrigation. However, if not 
installed properly, it may result in wastage of water, time, money and yield. Adoption of drip irrigation (surface or subsurface) system in sugarcane is technically feasible and economically viable and needs to be vigorously followed (Kaushal et al. 2012). Nitrogen is one of the most important key elements in the agricultural production of various crop plants, sugarcane crop responds well to the nitrogenous fertilizers in terms of their yield and economic produce. Sugarcane being a very exhaustive and extracting crop, removes about $205 \mathrm{~kg}$ nitrogen for yielding a crop of $100 \mathrm{t}^{-h^{-1}}$ and for sustaining productivity, nitrogen is replenished through chemical fertilizer @ $340 \mathrm{~kg} \cdot \mathrm{ha}^{-1}$ in sugarcane. In 2011, world production of sugarcane was 1,794 million tons (FAO STAT, 2011) which is much higher than other major crops such as maize (883 million tons), paddy rice (723 million tons), wheat (704 million tons) and potatoes (374 million tons). Sugarcane production is highest in Brazil (734 million tons), followed by India (342 million tons), and China (115 million tons). Sugarcane was cropped over an area of 25 million hectares all over the world; the average yield was 70.5 tons per hectare. It has occupied 40.75 lakh ha. Area in India, while 7.36 lakh ha. In Maharashtra state most of the sugar obtained in the world i.e. $60 \%$ is from sugarcane. Consortiums of endophytic bacteria include various bacteria like, Acetobacter, Agrobacterium, Burkhloderia, Azospirrilum, Herbaspirillum, Azoarcus etc. Acetobacter diazotrophicus now a day's known as Glucanoacetobacter diazotrophicus is an acid loving bacterium requiring $\mathrm{pH}$ of 4.0 to 4.5 for growth and $\mathrm{N}$ fixation. It showed positive growth at $25^{\circ}, 30^{\circ}$ and $40^{\circ} \mathrm{C}$ temperature. Among the biofertilizers, the endophytic bacteria Gluconacetobacter and Herbaspirillum are gaining more importance, since they fix atmospheric nitrogen endosymbiotically.

\section{Materials and Methods}

The investigation was carried out at AICRP on Water Management, M.P.K.V., Rahuri during 2014-15. Soil was medium black it belongs to Inceptisols. The climate of this area is semi-arid. The seedling material of sugarcane Co.M -0265 (Phule - 0265) was procured from Chief Scientist, AICRP on Water Management, Department of Agronomy, M.P.K.V., Rahuri. The experiment was laid out in RBD design with four replications and six treatments including one control and one recommended dose of fertilizers.

Basal dose of nitrogen, phosphorus, and potassium i.e. recommended dose (250:115:115 kg of $\mathrm{N}, \mathrm{P}_{2} \mathrm{O}_{5}$ and $\mathrm{K}_{2} \mathrm{O} \mathrm{ha}{ }^{-1}$ ) along with organic manures i.e. full dose of FYM, Acetobacter diazotrophicus and PSB as per the different treatment details per plot and replication wise were given before transplanting of seedlings. Remaining doses of fertilizers were applied at 6-8, 12-14, and 18-20 weeks after transplanting i.e. top dressing. Consortium of Endophytic Bacteria foliar spray were taken at 60 days after transplanting for treatments 4 and 5 in all the four replications. Two hand weedings were carried out to keep plots free from weeds. Irrigation schedule for drip at alternate day as per $100 \%$ ETc was fixed.

\section{Details of treatments}

$\mathrm{T}_{1}$ - Absolute control (No fertilizers),

$\mathrm{T}_{2}-\mathrm{RDF}\left(100 \% \mathrm{~N}, \mathrm{P}_{2} \mathrm{O}_{5}\right.$ and $\left.\mathrm{K}_{2} \mathrm{O}\right)$

$\mathrm{T}_{3}-50 \% \mathrm{~N}+$ Acetobacter diazotrophicus @ $10 \mathrm{~kg} \cdot \mathrm{ha}^{-1}$ (set treatment)

$\mathrm{T}_{4}-25 \% \mathrm{~N}+$ Consortium of Endophytic Bacteria @ $3 \mathrm{~L} \mathrm{ha}^{-1}$ (500L water ha ${ }^{-1}$ ) [foliar spray at $60 \mathrm{DAT}]$ 
$\mathrm{T}_{5}-0 \% \mathrm{~N}+$ Consortium of Endophytic Bacteria@3 L ha ${ }^{-1}\left(500 \mathrm{~L} \mathrm{ha}^{-1}\right)$ [foliar spray at $60 \mathrm{DAT}$ ]

$\mathrm{T}_{6}-0 \% \mathrm{~N}+$ without Consortium of Endophytic Bacteria.

Note: $75 \% \mathrm{P}_{2} \mathrm{O}_{5}, 100 \% \mathrm{~K}_{2} \mathrm{O}, 20$ t.ha ${ }^{-1} \mathrm{FYM}$, $1.25 \mathrm{~kg} \cdot \mathrm{ha}^{-1,}$

PSB common to all treatments except $T_{1}$.

The Consortia of Endophytic Nitrogen fixing bacteria was applied as foliar application@ @ 3 lit $\mathrm{ha}^{-1}$. (500 lit water) at 60 days after transplanting.

The following endophytic bacteria are the components of consortia:

Acetobacter

Agrobacterium

Burkhloderia

Azospirrillum

Herbaspillum

Azoarcus

\section{Harvesting}

Initially the ring lines of the gross plot were removed and the net plot harvesting was done on $7^{\text {th }}$ February, 2015, and the plot wise weights and observations were taken on the same day.

\section{Yield observations}

Five plants were randomly selected from each plot for recording number of Millable canes at 10 months age, and girth and length of internodes, number of internodes at harvest.

\section{Yield per net plot}

At the time of sugarcane crop harvest, the ring lines from all the sides of the plot were excluded and the yield per net plot was recorded in $\mathrm{kg}$. The weight was recorded using electronic balance.

\section{Yield per hectare}

Based on the yield per net plot and the plot size the yield per hectare was calculated and recorded in tonnes per hectare.

The data was analyzed statistically by using randomized block design as per procedure described by Panse and Sukhatme (1985).

\section{Results and Discussion}

The data regarding the number of internodes and girth and length of seasonal sugarcane is given in table 1 .

The treatment $T_{3}$ recorded highest number of internodes at harvest $(26.60)$ which was at par with the treatments $\mathrm{T}_{2}, \mathrm{~T}_{4}, \mathrm{~T}_{5}, \mathrm{~T}_{6}$ (25.50, $26.20,24.95,24.85$, respectively).

The lowest numbers of internodes (22.23) was observed in $\mathrm{T}_{1}$.

The highest mean girth of internodes of sugarcane at harvest $(12.40 \mathrm{~cm})$ was recorded in treatment $T_{2}$ which was at par with the treatment $\mathrm{T}_{4}(12.00 \mathrm{~cm})$. The least girth of internodes $(9.60 \mathrm{~cm})$ was observed in $T_{1}$.

The significantly highest internodal length of sugarcane at harvest $(15.55 \mathrm{~cm})$ was observed in treatment $\mathrm{T}_{3}$ however, it was at par with treatments $\mathrm{T}_{2}, \mathrm{~T}_{5}, \mathrm{~T}_{6}(15.50,15.00$, and 14.60, respectively). The least internodal length $(13.70 \mathrm{~cm})$ was observed in $T_{1}$.

This might be due to combined use of organic, inorganic fertilizers and biofertilizers which primarily improved the fertility status of soil and created congenial environment for better growth and development of sugarcane 
plant, thus improved internodes, cane girth with those reported by Mehta et al. (1996), and length. These results are in conformity Kumar (2012) and Soomro et al. (2013).

Table.1 Effect of consortium of endophytic nitrogen fixing bacteria on Internodes of seasonal sugarcane

\begin{tabular}{|c|l|c|c|c|}
\hline \multirow{2}{*}{ Sr. No } & \multicolumn{1}{|c|}{ Treatments } & \multicolumn{2}{c|}{ Internodes at Harvest } \\
\cline { 3 - 5 } & \multicolumn{1}{|c|}{$\begin{array}{c}\text { No. of } \\
\text { Internodes }\end{array}$} & $\begin{array}{c}\text { Girth } \\
\text { (cm) }\end{array}$ & $\begin{array}{c}\text { Length } \\
\text { (cm) }\end{array}$ \\
\hline $\mathrm{T}_{1}$ & Absolute control & 22.23 & 9.60 & 13.70 \\
\hline $\mathrm{T}_{2}$ & RDF $\left(100 \% \mathrm{~N}_{1} \mathrm{P}_{2} \mathrm{O}_{5}, \mathrm{~K}_{2} \mathrm{O}\right)$ & 25.50 & 12.40 & 15.50 \\
\hline $\mathrm{T}_{3}$ & $50 \% \mathrm{~N}+$ Acetobacter diazotrophicus & 26.60 & 11.60 & 15.55 \\
\hline $\mathrm{T}_{4}$ & $\begin{array}{l}\text { 25\% } \mathrm{N}+\text { consortium of endophytic bacteria } \\
\text { foliar spray }\end{array}$ & 26.20 & 12.00 & 14.10 \\
\hline $\mathrm{T}_{5}$ & $\begin{array}{l}\text { 0\% } \mathrm{N}+\text { consortium of endophytic bacteria } \\
\text { foliar spray }\end{array}$ & 24.95 & 11.65 & 15.00 \\
\hline $\mathrm{T}_{6}$ & $\begin{array}{l}\text { 0\% } \mathrm{N}+\text { without consortium of endophytic } \\
\text { bacteria foliar spray }\end{array}$ & 24.85 & 10.80 & 14.60 \\
\hline & S.Em. \pm & $\mathbf{0 . 7 2}$ & $\mathbf{0 . 2 3}$ & $\mathbf{0 . 3 5}$ \\
\hline & CD at $5 \%$ & $\mathbf{2 . 1 8}$ & $\mathbf{0 . 6 9}$ & $\mathbf{1 . 0 5}$ \\
\hline & Mean & $\mathbf{2 5 . 0 5}$ & $\mathbf{1 1 . 3 4}$ & $\mathbf{1 4 . 7 4}$ \\
\hline
\end{tabular}

Table.2 Effect of consortium of endophytic nitrogen fixing bacteria on millable canes and Yield of seasonal sugarcane

\begin{tabular}{|c|c|c|c|c|}
\hline Sr. No & Treatments & $\begin{array}{l}\text { No. of Millable } \\
\text { Canes per plant }\end{array}$ & $\begin{array}{l}\text { Top yield } \\
\left(\text { t.ha }^{-1}\right)\end{array}$ & $\begin{array}{c}\text { Cane Yield } \\
\left(\text { t.ha }^{-1}\right)\end{array}$ \\
\hline $\mathrm{T}_{1}$ & Absolute control & 6.92 & 10.04 & 183 \\
\hline $\mathrm{T}_{2}$ & $\mathrm{RDF}\left(100 \% \mathrm{~N}, \mathrm{P}_{2} \mathrm{O}_{5}, \mathrm{~K}_{2} \mathrm{O}\right)$ & 8.00 & 11.23 & 254 \\
\hline $\mathrm{T}_{3}$ & $50 \% \mathrm{~N}+$ Acetobacter diazotrophicus & 9.09 & 11.19 & 269 \\
\hline $\mathrm{T}_{4}$ & $25 \% \mathrm{~N}+$ consortium of endophytic bacteria foliar spray & 9.17 & 11.47 & 284 \\
\hline $\mathrm{T}_{5}$ & $0 \% \mathrm{~N}+$ consortium of endophytic bacteria foliar spray & 8.09 & 10.64 & 243 \\
\hline \multirow[t]{4}{*}{$\mathrm{T}_{6}$} & $\begin{array}{l}0 \% \mathrm{~N}+\text { without consortium of endophytic bacteria foliar } \\
\text { spray }\end{array}$ & 7.75 & 10.64 & 202 \\
\hline & S.Em. \pm & $\mathbf{0 . 2 4}$ & $\mathbf{0 . 2 3}$ & 9.34 \\
\hline & $\mathrm{CD}$ at $5 \%$ & 0.71 & 0.69 & 28.17 \\
\hline & Mean & 8.17 & 10.87 & 239 \\
\hline
\end{tabular}

\section{Yield observations}

The data regarding the yield observations are given in table 2. Which indicated that yield was significantly influenced by treatments.

The treatment $\mathrm{T}_{4}$ recorded significantly highest number of millable canes (9.17) and cane yield $\left(284\right.$ t.ha $\left.^{-1}\right)$ which were at par with treatment $\mathrm{T}_{3}$ (9.09 and 269), respectively. The least number of millable canes (6.92) and cane yield (183 t.ha $\left.{ }^{-1}\right)$ was observed in $\mathrm{T}_{1}$. The significantly highest top yield (11.47 t.ha ${ }^{1}$ ) was observed in treatment $T_{4}$ which were at par with treatment $T_{2}\left(11.23\right.$ t.ha $\left.^{-1}\right)$ and $T_{3}$ (11.19 t.ha $\left.^{-1}\right)$. The lowest top yield (10.04 t.ha $^{-1}$ ) was observed in $\mathrm{T}_{1}$.

Similar results were also reported by Mehta et al. (1996), Chauhan et al. (2010) and Babar et 
al. (2011) who opined that apportioning of nitrogen dose through soil and that harvested from the air by the endophytic bacteria, substiantiate the need of crop thereby improving the physiological conditions of photosynthetic activities leading to more yields. The rhizosphere soil condition with respect to moisture and other physical properties also plays a key role to accelerate the microbial activity, also might be due to drip irrigation which maintained the soil moisture.

\section{References}

Ando, S. 2010. Nitrogen fixation associated with endophytic bacteria. In Nitrogen Assimilation in Plants, Ed. Ohyama, T. and Sueyoshi, K. (Research Signpost, Kerala, India), pp. 215-231.

Babar, L. K., Iftikhar, T., Khan, H. N. and Makhdum, A. H. 2011. Agronomic trials on sugarcane crop under Faisalabad conditions, Pakistan. Pak. J. Bot., 43(2): 929-935.

Chauhan, H., Sharma, A. and Saini, S. K. 2010. Response of sugarcane to endophytic bacterial inoculation, Indian J. Sug. Tech. 25 (1\&2): 1-4.

Kaushal, A., Rahul Patole and Singh, K.G. 2012. Drip Irrigation in Sugarcane: A
Review. Agri. Reviews, 33 (3): 211 219.

Kumar, N. 2012. Productivity, quality and nutrient balance in spring sugarcane (Saccharum spp. hybrid complex) under organic and inorganic nutrition, Indian J. Agron. 57(1): 68-73.

Mehta, H. N., Upadhyay, P. N., Chavda, J. R. and Patel, J. B. 1996. Effect of integrated nutrient management on yield, quality and economics of sugarcane (saccharam officinaram). Indian J. Agron. 41(1). 176-178.

Panse, V. G. and Sukhatme, P. V. 1985. Statistical methods for agricultural workers. Fourth Ed. ICAR, New Delhi. 157-165.

Reis, V., Lee, S. and Kennedy, C. 2007. Biological nitrogen fixation in sugarcane. p. 213-232. In: Associative and Endophytic Nitrogen-fixing Bacteria and Cyanobacterial Associations, Ed. Emerich, C. and Newton W.E., Springer, Dordrecht, The Netherlands. pp. 213-232.

Soomro, A. F., Tunio, S., Oad, F.C. and Rajper, I. 2013. Integrated effect of inorganic and organic fertilizers on the yield and quality of sugarcane (Saccharum officinarum L). Pak. J. Bot., 45(4): 1339-1348.

\section{How to cite this article:}

Rajkumar, B., B.D. Bhakare and Jana Harish. 2017. Effect of Consortium of Endophytic Nitrogen Fixing Bacteria on Yield Observations of Seasonal (Suru) Sugarcane under Drip Irrigation. Int.J.Curr.Microbiol.App.Sci. 6(7): 2789-2793. doi: https://doi.org/10.20546/ijcmas.2017.607.389 